\title{
Grassroots Environmental Activism in an Authoritarian Context: The Trees Movement in Vietnam
}

\author{
Ngoc Anh $\mathrm{Vu}^{1}$ (D)
}

Published online: 30 January 2017

(C) The Author(s) 2017. This article is published with open access at Springerlink.com

\begin{abstract}
There are increasing signs that the space for civil society actions is slowly opening up in Vietnam. The existing studies have linked the changes in civil society action to the changing dynamics of state-society relations in one-party-ruled Vietnam. Yet, the majority of this literature has focused on the activities of NGOs. This article fills this gap by highlighting a high-profile case of civil society activism that is not centred on NGO actions. The Trees Movement is a broad-based citizenled movement established to protest against Hanoi government's arbitrary decision to cut down thousands of large old trees lining the city's streets. I use this case study to argue that citizen-led activism, an emerging form of civic engagement, is likely to play a critical role in effecting change and (re)shaping state-society relations in Vietnam. This form of activism, if sustained, will encourage a move toward more deliberative and accountable politics in the same country in the long run. I also argue that environmental activism has opened up a new arena of contestation for civil society activism in Vietnam.
\end{abstract}

Résumé Des signes de plus en plus visibles annoncent que l'espace propice aux actions de la société civile s'ouvre doucement au Vietnam. Les études existantes ont dressé un lien entre les changements desdites actions et les dynamiques en constante évolution des relations État-société d'un Vietnam à parti unique. La majorité de cette documentation s'est pourtant concentrée sur les activités des ONG. Le présent article comble cette lacune en faisant la lumière sur un cas réputé d'activisme de société civile non centré sur des actions d'ONG. Le Trees movement (TM) est un mouvement citoyen global mis sur pied pour protester contre la décision arbitraire du gouvernement d'Hanoï d'abattre des milliers d'arbres anciens et massifs le long

Ngoc Anh Vu

tnav20@bath.ac.uk; ngocanhvu58@gmail.com

1 Department of Social \& Policy Sciences, University of Bath, Claverton Down Rd, Bath, North East Somerset, Bath BA2 7AY, UK 
des rues de la ville. J'ai utilisé cette étude de cas pour avancer que l'activisme citoyen, une forme émergente d'engagement civique, jouera vraisemblablement un rôle essentiel dans la transformation et la (re)création des relations État-société au Vietnam. Cette forme d'activisme, si elle est soutenue, favorisera une transition vers l'élaboration de politiques plus délibérées et responsables à long terme dans le pays. J'avance aussi que l'activisme environnemental a ouvert une nouvelle scène de contestation pour l'activisme de société civile au Vietnam.

Zusammenfassung Es gibt vermehrt Anzeichen dafür, dass es in Vietnam langsam Platz gibt für bürgergesellschaftliche Aktionen. Vorliegende Studien bringen die Veränderungen hinsichtlich bürgergesellschaftlicher Aktionen mit der sich ändernden Dynamik der Beziehungen zwischen Staat und Gesellschaft im Einparteiensystem von Vietnam in Verbindung. Doch konzentriert sich der Großteil der Literatur auf die Aktivitäten von Nichtregierungsorganisationen (NROs). Der vorliegende Beitrag schließt diese Lücke, indem er auf einen bekannten Fall des bürgergesellschaftlichen Aktivismus eingeht, bei dem nicht die Aktivitäten von NROs im Mittelpunkt stehen. Die Trees Movement (TM) ist eine breit angelegte Bürgerbewegung als Protest gegen die willkürliche Entscheidung der Stadtverwaltung von Hanoi, Tausende großer alter Bäume zu fällen, die die Straßen der Stadt säumen. Beruhend auf dieser Fallstudie wird argumentiert, dass der Bürgeraktivismus als eine neue Form des Bürgerengagements wahrscheinlich eine wichtige Rolle dabei spielt, Änderungen herbeizuführen und die Beziehungen zwischen Staat und Gesellschaft in Vietnam (neu) zu gestalten. Diese Form des Aktivismus, sofern er anhält, wird in dem Land langfristig eine Bewegung in Richtung deliberative und verantwortliche Politik fördern. Es wird zudem behauptet, dass der Umweltaktivismus für den bürgergesellschaftlichen Aktivismus einen neuen Raum für den Widerstand in Vietnam geschaffen hat.

Resumen Hay señales crecientes de que el espacio para las acciones de la sociedad civil se está abriendo lentamente en Vietnam. Los estudios existentes han vinculado los cambios en la acción de la sociedad civil con la dinámica cambiante de las relaciones estado-sociedad en un Vietnam gobernado por un partido. Sin embargo, la mayoría de este material publicado se ha centrado en las actividades de las ONG. El presente artículo llena este vacío destacando un caso de alto perfil de activismo de la sociedad civil que no se centra en acciones de ONG. El Movimiento a favor de los Árboles (TM, por sus siglas en inglés) es un movimiento de amplia base liderado por ciudadanos establecido para protestar contra la decisión arbitraria del gobierno de Hanói de cortar miles de grandes árboles viejos que bordean las calles de la ciudad. Utilizo este estudio de caso para argumentar que el activismo liderado por ciudadanos, una forma emergente de compromiso cívico, probablemente desempeñe un papel crítico efectuando el cambio y (volviendo a dar) dando forma a las relaciones estado-sociedad en Vietnam. Esta forma de activismo, si se apoya, alentará un movimiento hacia políticas más deliberativas y responsables en el mismo país a largo plazo. También argumento que el activismo medioambiental ha abierto una nueva área de oposición para el activismo de la sociedad civil en Vietnam. 
Keywords Vietnam · Trees Movement · Civil society activism · Citizen-led mobilization $\cdot$ NGOs

\section{Introduction}

"I can't understand this, I can't understand why they (the city government) are doing this? I can't understand what is actually behind this recklessness? Tons of bombs B52 by Americans failed to destroy our old trees during wartime, why authorities dare to cut them down now? [...] If they defend what they are trying to do is for a more civilized and modern Hanoi, why do they start from cutting trees when there are countless problems that are more urgent directly associated with the infrastructure and living quality in Hanoi?" (Interview, 14 April 2015, Hanoi).

It was a warm March in 2015 when spring atmosphere was lingering in the streets of Hanoi. All corners of the capital city were displayed with red-coloured banners written with yellow-coloured slogan "Greet the Party, Greet Spring", which for decades has become an indispensable part of the Vietnamese society to honour the Communist party when spring comes. The city, with its distinctive beauty of treefringed boulevards, was vibrating. It vibrated not because of an earthquake or a natural calamity, but due to the felling of trees by human hands. The unusual project of the city administration in cutting down 6708 trees in 190 streets across the capital city sparked public outcry.

In non-democratic regimes like Vietnam, where public fear still prevails because of the state coercion, e.g. any act of criticism might be arbitrarily put under such a label as 'regime opposition'. Violent repression has not faded away and can be seen in many cases where democratic activists have been exposed to a range of state repression measures such as humiliating, harassing, physical attack, damaging livelihoods, detainment and arrest.

There are increasing signs, however, that the space for civil society action is slowly opening up in Vietnam. The existing studies have linked changes in civil society action to the changing dynamics of state-society relations in one-party-ruled Vietnam. Yet, the majority of this literature has focused on the activities of NGOs, the formal structure of civil society organization, for they are officially organized and their actions are more permitted. This apparently makes NGOs less challenging to study, especially for foreign researchers, compared to the organic and spontaneous social movements.

The article will fill this gap in the literature by focusing on a high-profile case of civil society activism that is not centred on NGO action. It brings to the forefront the 'Trees Movement' (TM), a very recent broad-based citizen-led movement established to protest against a government decision to cut down thousands of large old trees which line the streets of Hanoi. It will examine processes in which different civic groups orchestrate collective actions to request the government to stop cutting down the trees and also to demand a deliberative and accountable government. It will also explore the ways in which this movement informs us of the 
changing dynamics of state-society relations in Vietnam. Most importantly, however, I will use this case study to argue that citizen-led activism, an emerging form of civic engagement, is likely to play a critical role in effecting change and (re) shaping state-society relations in Vietnam. This is because it signifies the political elites that how civilians could orchestrate rightful civic actions to oppose unpopular state decisions and policies. This form of activism, if sustained, will encourage a move toward more deliberative and accountable politics in Vietnam in the long run.

Drawing on the TM, I will highlight how strategically organized nonviolent resistance opens up opportunities for civil society groups wishing to stand up to the state. The citizen-led TM is not restricted to any political rhetoric, nor is it agitated by a particular political ideology, religion or social class. Neither does it have a single identifiable leader, nor does it have diffusive leadership. From the façade, it seems to be loosely structured, clandestine, and non-hierarchical; however, underneath it is well-organized, professionalized and hierarchical. It critically resorts to the interplay of formal and informal channels, strategizing the online activism coupled with real-life peaceful demonstrations, building legitimacy for its activism through appeal to the Constitution and nesting within state agenda and discourse. What is particularly interesting about this case is that it is not led by NGOs or any other organized civil society form. The impetus for its collective actions comes from a broad-based coalition of citizens across societal spectrums.

As it evolved, the TM secured the support of both registered NGOs and informal/ unregistered groups (including independent activists associated with 'reactionary forces' by the ruling communists). The surreptitious coalition of the registered and unregistered groups is unprecedented in Vietnam and triggered a more state tolerance as well as created opportunities for further civic actions. This phenomenon resonates with the recent social movements elsewhere such as the Arab Spring, the anti-austerity and anti-capitalist movements in many parts of Europe, where activists and NGOs embarked on a relationship which Glasius and Ishkanian (2014, p. 3) refer to as "surreptitious symbiosis" to maintain activism and bring about social change.

The paper will examine how and why the tree campaigners embarked on a specific repertoire of contentious actions by capturing the evolution of the movement and dynamics of its activism. Bringing insights to the case of the TM, I further argue that environmental activism has opened up a new arena of contestation for civil society activism in Vietnam.

\section{Methodology}

The paper draws on my eight-month ethnographic research into civil society activism in Vietnam. The TM that burst out in Hanoi in mid-March 2015 in Hanoi coincided with the period of my field research, which was therefore opportune for me to become involved to capture fresh and real-life moments of the movement as a marginal participant. During this time, I followed closely the TM and collected primary data from extended conversations, in-depth interviews and group discussions, with a wide range of actors who were closely associated with the movement 
including independent activists, dissidents, bloggers, lawyers, local NGO leaders, human rights experts, artists, intellectuals, students, housewives and etc.

Being a marginal participant of the movement allowed me to identify prominent campaigners who became my key respondents and some of whom helped refer me to other 'hidden' independent activists who played an important role in the campaign. What is notified here is that 'independent activists' and 'dissidents' for the ruling communists in Vietnam are trouble makers, dangerous, and disturbing group, and branded as 'reactionary or hostile forces'. This label successfully isolates them from general population. Therefore, gaining access to them requires a certain degree of trust to be established for their safety reasons. On this ground, snowball sampling was finally used in order to access this hidden and hard-to-reach population.

The trees saving campaign evolved amid the intense atmosphere in Hanoi covered with the increasing harassment and intimidation by the security forces. Being born and growing up in Vietnam enabled me to have my own subjectivity to find the way to work with 'sensitive' actors such as independent activists and dissidents, those labelled as hostile or reactionary forces and whose role was of importance in the movement. It particularly gave me strong sense of prudence about what I should do, whom I should contact, how, when, and where I should do it. As a matter of fact, working or interacting directly with independent activists and dissidents in the politically sensitive environment such as Vietnam might induce risks for both foreign and even Vietnamese researchers. However, being a Vietnamese, needless to say, put me in a stronger position to study this social movement than foreign researchers. The reason why I said so rests on the fact that for dissidents and independent activists, their individual acts or criticism will be to some extent tolerated as long as they do not seek to assemble with others or have no linkage to foreigners. Risk of repression will be higher for those who are seen to be linked with foreign actors, no matter who foreigners are. Yet, having said that does not mean that I was not aware of the challenge of my positionality, i.e. this case study happened in my city; therefore, how to keep a balance between a dispassionate researcher and a passionate supporter of the movement became an important exercise that needed to be addressed cautiously.

Taking advantage of my 'insider knowledge', I strived to provide an in-depth bottom-up account about the meaning and outcome of one of the most significant episodes of public contestation in Vietnam in recent years: the campaign to save Hanoi's trees in 2015. The movement started in mid-March 2015 and diluted in July 2015, three months later.

My interview questions focused on the campaigners' motivations, targets, beliefs, aspirations, and their tactics and repertoire of actions, discourses and slogans, and their relationship with other groups in the TM. The interviews were undertaken in various forms ranging from instant interviews with random participants I met in the demonstrations, to unstructured and semi-structured interviews, and sometimes in the form of extended conversations. Except the instant, the interviews lasted between 2 and $3 \mathrm{~h}$ and were conducted in Vietnamese in March-July 2015. In several instances, follow-up communication was made via emails, Facebook and Skype. The interviews were then translated into English to make it easier for coding 
process aided by NVIVO software. Since questions were politically sensitive, interviews and respondents were anonymized, and pseudonyms were used. However, in some cases, it was not reasonable or possible to follow the pseudonym and anonymization strategy when the names of Facebook pages or Facebook groups, names of certain actors or organizations were publicly covered on either mainstream or social media. Falling in this situation, prompted by Devine (1999)'s dual strategy, I decided not to change the names when these instances were already circulated in the media, but where I used the information collected from personal interviews with these same actors, I had to anonymize them.

Before setting out the dynamic activism pertaining to the TM, I will critically review selected literatures on civil society and social movement. There are substantial limitations concerning these theories. As we will later see, each theory itself falls short of explaining the changing dynamics of state-society relations in authoritarian contexts such as Vietnam, where the dominant structural accounts of civil society concept and overt forms of political contention-the pivot of dominant social movement theory-do not fit well into the recurring Vietnamese civil society practice. The aim of this review is to critique these theories and set out a need for a more productive alternative framework which is plausible enough to explain the intricacies of evolving state-society relations in the one-party-ruled Vietnam.

\section{Civil Society Activism in Authoritarian Contexts}

Civil society activism in authoritarian contexts has triggered academic attention and paves the way to the development of a new wave of research; the existing literature on this topic remains, however, limited in terms of ideas. Large account is limited to circumstances of specific country contexts, and little attempt is aimed at approaching the topic from a comparative politics perspective with cross-country analysis. Contemporarily, there is a single book titled 'Civil society activism under authoritarian rule' edited by Francesco Cavatorta (2012) in an attempt to bring together different pieces of writings produced on the ground of different specific country contexts. In this book, Cavatorta (2012, p. 2) argues that the myth about civil society as an instrument of democratic change in non-democratic regimes needs to be contested and introduces the concept "activated citizenship" with an aim to capture the complexity of forms of expressions by civil society in this political environment.

The rendezvous between non-democratic political systems and varying forms of associations outside the state apparatus, and adding to that is the growing grassroots activism, all in all contributes to making state-society relations under these regimes more complex, which often takes issue with the dominant civil society theory. Despite the variability of approaches to researching this topic, there are a number of common observations within this emerging literature. Due to the limited space of the paper, I will only present three most prominent perspectives growing out of this emerging scholarly work. 


\section{Weakness of Liberal Perspective}

Much of the scholarly work on civil society activism in authoritarianism contradicts the dominant liberal perspective that portrays civil society as a distinct sphere from the state and as a site of confrontation to state hegemony (e.g. Teets 2014; Hannah 2007; Cheskin and March 2015).

Civil society theory in modern times is dominated by political liberal tradition which is deeply rooted in Tocquevillean thinking. Although it has evolved since Tocqueville, it persistently remains revolved within the locus of the Western-centric view. Salient to the liberal view is its emphasis on the autonomy of civil society as a requisite towards a functioning and robust civil society. It strongly ascribes civil society with democratic role (Chandhoke 1995). The liberal's emphasis on statesociety divide is criticized too static and reductionist, which is unable to explain the complexity and changing dynamic of state-civil society relations in many developing countries especially in non-democratic regimes such as Vietnam where patterns of state-society interactions and intersections run counter to many of the assumptions underpinning especially the western model of civil society.

\section{Civil Society and Contested Phenomenon}

The reductionism of the liberal perspective is detrimental to understanding analytically changing state-society relations in non-democratic regimes; much of the new work on the topic therefore appeals to a more critical approach, the Gramscian perspective. The reasons for championing Gramsci rest on that he conceives civil society as a contested sphere with discursive nature, and he transforms simplistic form of state dictatorship into state hegemony over society through domination and consent (Fontana 2002; Ramasamy 2004; Landau 2008).

Due to the weak fit between liberal perspective and civil society practice in authoritarian contexts, the Gramscian perspective becomes favoured as an alternative approach in these contexts (Landau 2008). It is agreed that to some certain degree, the Gramscian approach takes effect in elucidating some important aspects of civil society in authoritarian contexts; nevertheless, it is inadequate to explain the complexity and transformation of state-society relations in these countries. For example, it is observed that elsewhere some forms of association have succeeded in circumventing or navigating the state's hegemonic power by appropriating the system to make it work for their organizational purpose (Bui 2013).

Critically, the current state of civil society theory is deeply rooted in a eurocentric view of state-society relations. It more or less provides a good structural account of relationship between state and society (Brown 2004). Nevertheless, there are certain limitations to this theory that even become impediments to properly understanding dynamic state-society relations in the political context of authoritarian regimes. 


\section{Beyond Civil Society}

The rise to prominence of collective action from below in many authoritarian political systems (such as Vietnam, China, Burma, Russia) has contested further the efficiency of the dominant civil society theory in explaining the emerging phenomenon, and also necessitated the search for an alternative conceptual framework which is sufficient to understand analytically these episodes of public contestation which influence the changing state-society relations in these contexts. Given this, social movement theory is therefore employed with particular attention to its dominant explanatory terms (e.g. contentious collective action, political opportunity, mobilizing structures and framing processes) with an aim to examine these changing dynamics.

The terms above indicated are the locus of the political process theory (PPT) developed by the leading American theorists of social movement theory in the contemporary period (e.g. McCarthy and Zald 1977; Tarrow 1994; McAdam 2010; Tilly and Tarrow 2015). Under the PPT, people engage in contentious politics in response to political opportunities and then through collective action, create new ones (Tarrow 1994). It implies that the emergence of political opportunities is a prerequisite and particularly, that groups even with deep grievances and dense network of resources but lacking opportunities may not appear in movement (ibid).

Yet, the existing scholarship of civil society activism in authoritarian contexts contend that although the explanatory terms as discussed above are useful to explain specific moments of contention, the model places too much emphasis on the movements targeting at the state or overt forms of political contestation (Cheskin and March 2015; Goodwin and Jasper 2004). As a result, only movements and forms of activism that confront directly the state and politically challenge its status quo are favoured. The prism of this emphasis dismisses a range of forms of civic mobilization/activism at which confrontation with the state is not always overt and straightforward, which is a common practice of public sphere in many nondemocratic regimes including Vietnam.

The existing scholarship on civil society activism in Vietnam tends to lay more focus on formal organizations or classic civil society activism (i.e. led by formal structures/associations), for example, the work by Irene Norlund (2007); Kerkvliet et al. (2008); Hannah (2007); or extensive work by Wischermann (2003, 2013) on civic organizations and issue-oriented organizations. Particularly, research on this topic written by Vietnamese is very peripheral, and the available work is again either focused on for example stereotypical categorization of civil society organizations (Bui 2005) or on socio-economic functions of civil society organizations (Sinh 2003, 2011).

Equally notable is that research on grassroots activism in Vietnam remains a significant lacuna. Recently, there are some emerging accounts on non-traditional and non-hierarchical forms of activism such as Wells-Dang $(2010,2011)$ with focus on informal civil society networks and political space claimed from below, Thayer (2009) with particular focus on autonomous civil society which he refers to as political civil society, Morris-Jung (2015) on online petition movement, especially 
large account by Ben Kerkvliet on workers' protests (2010), farmers' protests (2014a), and notably his unique account on opposition and dissidents (2014b).

This paper focuses on grassroots citizen-led movement, one of the most significant episodes of public contestation in Vietnam in recent years: the movement to save Hanoi's trees in 2015. I will bring insight into how activism was waged from below and played out by both the organized/formal group (local NGOs) and unorganized/informal group (independent activists) in this movement to successfully make the government respond for the sake of the city citizens.

\section{Trees Movement: A New Form of Civic Engagement in Vietnam}

\section{Setting of the Trees Movement (TM)}

In November 2013, Hanoi Department of Construction submitted to the city People's Committee its proposal for approval of the scheme of renovating and replacing trees in urban Hanoi during the period 2014-2015 (Hanoi Construction Department's Proposal No. 8542/TTr-SXD), which was referred to as "tree-felling project" by Hanoians, while the government repeatedly framed it as a landscaping project, not tree-felling. Its estimated cost was VND73.38 billion (equivalent to \$US3.4 million), for which the funding would come from the city's budget. The project, as the department indicated, was aimed to replace the old and decaying trees with other types of trees or plants considered more suitable to the city outlook. On 18 March 2014, the Hanoi People's Committee adopted the department proposal, which was evidenced in the Decision No. 6816/QD-UBND it issued. As many as 6708 green trees, making up more than a quarter of the total city greenery, would be cut down and/or replaced for the reasons such as these trees were either dying, decayed, or bent, or posing risks to road users during rainy seasons, or different kinds of trees were planted on the same street creating a poor aesthetic outlook (implying that the government wanted trees planted in lieu to be uniformed), or trees were detrimental to planned infrastructure projects (according to this Proposal). However, the Hanoians observed in reality that the majority of trees being chopped were healthy, luxuriant, century-old planted during the era of the French colonialists, and their timber would generate a huge source of income (see Figs. 1, 2 ), meanwhile the department provided no information of what they would do with the large volume of timber from the felled trees.

Numerous questions and concerns arose and centred on the project legitimacy and rationality. Overwhelming the city during those days was an intense atmosphere filled with public anger towards the municipal authorities for their unpopular decision to cut down trees without any public consultation. As a protester put it:

Why thousands of trees have to be chopped down all at once? I agree there are some trees which can cause danger to pedestrians and drivers during the storm season, but cutting their unsuitable branches is more than enough, not whole trees; for those trees unfit to the aesthetic city landscape as the authority persistently defends, they should be removed and replanted elsewhere rather 


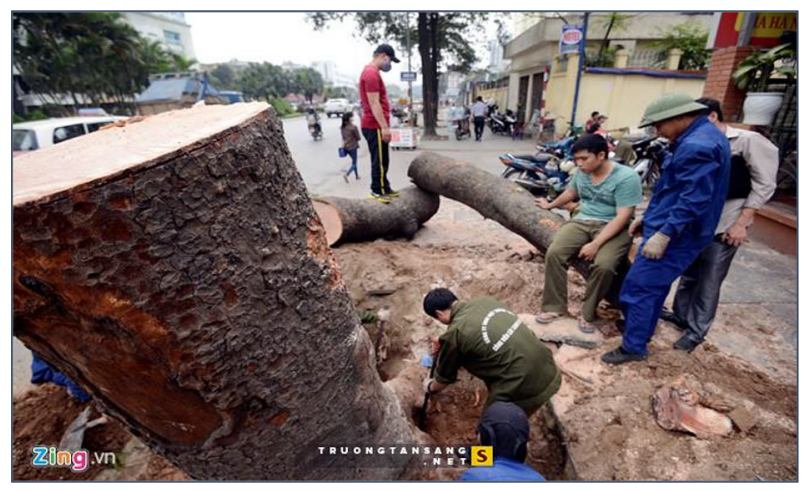

Fig. 1 Healthy old trees were chopped down. Hanoi looked like a construction site. Source http://www. doisongphapluat.com. Available at http://www.doisongphapluat.com/xa-hoi/ha-noi-chat-6700-cay-xanhgs-ngo-bao-chau-len-tieng-a87881.html

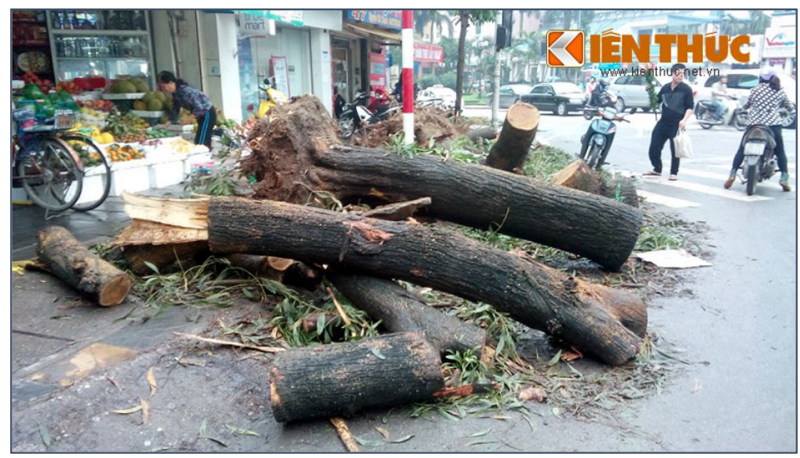

Fig. 2 Healthy old trees were chopped down. Hanoi looked like a construction site. Source http://www. kienthuc.net.vn. Available at http://www.kienthuc.net.vn/soi-xet/ha-noi-xin-khat-hang-loat-cau-hoi-vuchat-cay-xanh-468493.html

than being chopped down. It is heart-breaking. How many years do we have to wait to have shade from trees again, which is really needed in this city where thousands of street vendors and labourers are every single day grappling with the heat in burning summers? (Interview, 18 March, 2016, Hanoi).

Trees were cut down here, and there in different streets of Hanoi since early March. On 19-20 March 2015, hundreds of trees alongside Nguyen Chi Thanh Street, known as one of the most beautiful boulevards in Vietnam, the first selected street subject to the tree-felling project, were cut down. Earlier, Mr. Le Van Duc, Director of the Hanoi Construction Department, stated in a mainstream newspaper that "Total 381 shade trees of 15 species on Nguyen Chi Thanh Street, which prompts a lack of uniformity, will be replaced by Manglietia Dandyi". The new trees, he said, were of high value and would provide a better aesthetical outlook for the city. However, these saplings looked unhealthy and almost unable to grow after being planted in reality (see Fig. 3). Local scientists proved that these trees are in 


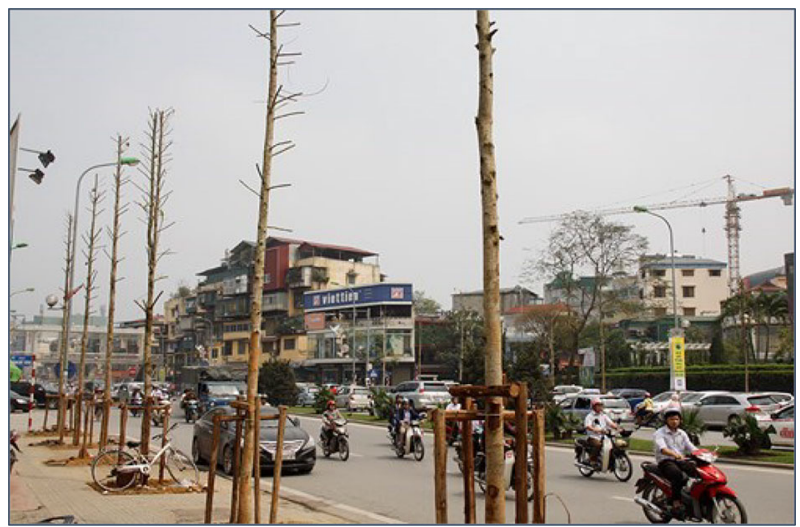

Fig. 3 Trees replanted in Nguyen Chi Thanh street after all big old trees in this street were chopped down. Source http://www.thanhnien.vn. Available at http://www.thanhnien.vn/thoi-su/ha-noi-thay-thecay-xanh-cay-moi-trong-khong-phai-vang-tam-543702.html

fact Magnolia conifera, ${ }^{1}$ a deciduous tree native to China which grows up to $30 \mathrm{~m}$ in height, and it is among species that are not recommended to be planted in urban streets (Thanh Nien News 2015). As quickly as within just a few days, Hanoi looked like a construction site with loads of large healthy trees being cut into logs and spread on the ground. Within a very short period of time, as many as 2000 trees which included a large number of old and valuable trees were completely cut down.

It was a despair for Hanoians to realize that as many as 6700 trees had been in queue to be cut down, and in fact, almost two thousand trees were already destroyed. It was such unease for them to understand why green trees of their beloved city could not be defeated by tons of bombs during wartime but then were relentlessly destroyed in peacetime by arbitrary decisions. More dramatically, authorities did it without a single attempt to seek public opinions, closed all doors to publics, and prolonged their quiescence as long as possible in order to demotivate civic response.

On this ground, people realized that mourning to pay tribute to felled, being felled and will-be-felled trees was pointless. Only action could help save their city. The social media was on fire when Facebook users every minute updated with new images about felled trees or warnings of next trees to be felled, accompanied with messages conveying emotional reactions. To pacify public outcry, the head of the Hanoi People's Committee (i.e. the city government) decided to put the project on halt and a handful of low-ranking officials of Department of Construction (but none from the Hanoi People's Committee) were temporarily suspended. This was not enough, however. A blogger, also an activist stated "this is just a cosmetic tactic of the city administration".

Hanoians value their city heritage and have pride of it. Tree after tree was cut down without consulting public opinions. They wanted to hear responsible answers

\footnotetext{
1 Manglietia Dandyi and Magnolia conifer are very much different in price, the former costs about \$US 2000 to 2500/each tree while the latter is about \$US50.
} 
from the city government to the unanswered questions such as "Why streets in Hanoi have to wear 'manglietia dandyi' uniform?", "Why most of felled trees are healthy ones?", "Where is the timber of the felled trees (its estimated value is worth millions of dollars) and how the government will deal with it?" and hundreds of questions from journalists, scientists, and citizens remained unanswered.

In the sections which follow, I will first analyse why and how people took to the streets in the TM. I will then investigate how the TM orchestrated its activism effectively based on the use of the internet and finally examine how the TM, starting out as an environmental campaign, created a new space of contestation that aimed at achieving more deliberative and accountable politics in Vietnam.

\section{A Moment to Spark: Constructive Nonviolent Tension}

A good point of entry is to trace back how people's consciousness was awakened and decided to take on to the streets. In the single-party-ruled Vietnam where seeking refuge in silence is a more favoured habit rather than speaking out, and fundamental democratic institutions such as law on demonstration, law on association, or law on referendum are still absent, rallying in streets to protest against the government decision as observed in the TM is not commonplace. As Dr. Nguyen Quang A, a dissident, noticed "The tree saving campaign in Hanoi has awakened civil society in Vietnam. It is an encouraging sign for civil society activists" (RFI 2015).

What so awoke people to converge together to rise up in the TM? More precisely what provoked them to decide to act? From silence to protest, this process needs some catalysts to gather momentum. Several respondents highlighted that there were numerous instances in Hanoi in which the municipal government were either neglectful or lagging to respond to public concerns. However, people's habitual response was either to lament to themselves or keep muted irrespective of the consequence of that decision or policy that could negatively affect their everyday lives (for instance, escalating price of petroleum and electricity, rampant red tape in public administration offices, or widespread selling of fake medicines). But why did they choose to respond differently in the TM, i.e. speaking out and taking to the streets?

Hanoians are proud of their city green heritage together with its intensity of historical and cultural values. Many of the campaigners grew up in Hanoi and fought for the city, throughout time the old trees become their companions. An emotional bond exists between trees and Hanoians. The charm of Hanoi is laid to old trees, and they make the city boulevards come alive. Hanoians love them in many respects.

The government's tree-felling project sparked public anger. Only within a few days, the campaign momentum was gathered through Facebook, an alternative platform that allowed people to share freely their sentiments: sorrow, disenchantment, wrath and especially to connect freely to each other.

These sentiments, however, simply constituted a runway for collective action to take off. A dramatic or transformative event is needed to liberate cognition, trigger contentious momentum and compel people to take to the streets. Social movements 
elsewhere were often seen to be sparked by the sacrifice of someone whom Castells (2012) refers to as a rebel hero, either it be immolation or martyrdom for example. Humiliation provoked by the cynicism and arrogance of those in power was the prime cause of public protests, Castells indicates. In the TM, there was neither immolation nor martyrdom nor a rebel hero of any type, but humiliation emerged as a decisive factor that climaxed the contentious momentum and transformed the emotion of fear. People felt disgraced and humiliated by the cynical and arrogant statement of Mr. Phan Dang Long, the Deputy Head of the Hanoi Party Committee's Propaganda Department. On 17 March 2015, being asked by a reporter of a local media about whether it was necessary to consult publics in replacing trees, he replied, "There is no need to ask for public opinions" (Vietnamnet 2015a, b).

Mr Long's announcement likened to a bullet fired into people's trust (Le et al. 2016) emerged as a dramatic event triggering the momentum of contention to climax and caused people to take to the streets. Humiliation ably transformed the emotion of fear. This transformative event, according to Johnston and Carnesecca (2014), marked a turning point in the social construction of consciousness that triggered the momentum of contention, whereby it would manage, mitigate, and/or transcend fear, a principal deterrent to collective action in the authoritarian state, into several innovative oppositional repertoires. These repertoires, they explain, would draw larger segments of the population to take part in the movement, then to intensify momentum for collective mobilization. In the conception of the dominant social movement theory, this event could be understood as a political opportunity that requires collective mobilizers to take advantage of and quickly convert it into the mobilizing structure and actions conducive to achieving the collective goals. The green campaigners in the TM articulated this opportunity and brought people to the streets.

\section{The TM: Emergence, Structure, and Organization}

The TM brought about a glaring example of how the use of internet (e.g. social media sites) opened an alternative public sphere for civilians to exhibit contention. In the TM, it was instrumental for civic resistance to the city government's treefelling plan. Mobilizing support, calling for action, petition signing, coordinating and organizing rally points and events were orchestrated on social media sites (mostly Facebook in this case). The viral diffusion of images, ideas, sentimental expressions of people from all ages and backgrounds on social media was allegedly conducive to the tree saving campaign by Hanoians. A large scholarship (notably such as Castells 2012; Hoffmann 2011; Lotan et al. 2011; Smith 2011) recently depicts how social media changes state-society relations and provides an alternative public sphere for civic debates and discussions in authoritarian regimes. In Vietnam, independent press is not allowed to exist, hundreds of local newspapers and over 60 TV and radio stations are under absolute control of the party state. However, unlike China, Vietnam fails to block social media, e.g. Facebook or Twitter. Facebook, now used by over 22 million people (making up one thirds of the population), is 
among most favoured venues (Gray 2015). Thuy Minh, a blogger, and a member of Green Hanoi Group, illustrated as follows:

Facebook offers us a space for unrestrained deliberation and coordinated action. In this movement let's assume if there were no Facebook, they might have finished the felling of trees long before people could react. (Interview, 20 May 2015, Hanoi).

By virtue of the TM activism waged mainly via Facebook groups, it was crucial for me to be a member of these groups, and I managed to do so. Being 'inside' opened much room for me to gain a great insight into how they were organized and structured, and how they communicated internally and externally. It came to my recognition that the leading Facebook pages of the TM groups were structured as the concentric circles, the core of which was inhabited by administrators and task force groups; next to it was supporters ready to participate in activities initiated by the group page; the next outer circle was where those who showed their interest by clicking 'Like', 'Share', giving comments, sharing information via their own pages and including observers. An NGO leader, also a key member of the Group 6700 People, stated as follows:

How a page works depends heavily on the core group. They shape the culture of deliberation on the page and influence the attitudes of the participants. This could be seen in the content, language, spirit and attitude reflected in the TM pages. We endeavoured to maintain a deliberative space in a democratic and open manner in order to maintain dialogues between us and the people who followed the page and between the tree campaigners and the authorities in a constructive spirit. (Interview, 14 April 2015, Hanoi).

The TM membership was heterogeneous, unrestricted to any specific marginalized group. It attracted a wide range of participation cutting across social spectrums, be they women, men, the old, the young, the rich, the poor, intellectuals, artists, scientists, business, academics, lawyers, journalists, registered local NGO staff, bloggers, activists, housewives, etc. Salient to this movement is that it was completely localized with no support from international donors and INGOs in terms of resources. Some staff of embassies and INGOs participated in the peaceful demonstrations not on behalf of their organization but as individuals. Most of the interview respondents from the mobilizing groups revealed that they did not feel convinced about the need to involve external actors since they thought Vietnamese people could handle this issue. Particularly a critical insight they indicated was related to the nature of the external actors' engagement. This implied that the movement was in essence spontaneous and impromptu while international donors and INGOs who worked officially in Vietnam were project-and/or programmedriven. They add that it was also rare to see these institutions put themselves in direct opposition to the local government for their both short- and long-term missions and commitments.

There were three groups which stood out in the TM: Group 6700 People (the pioneering group and also managing the Fan page 6700 people for 6700 trees), Group 6700 trees, and Group for a green Hanoi. However, a kick-off to the 
movement did not come from any of the groups above but from an open letter of an individual, Mr. Tran Dang Tuan, who is a reputable journalist, a former deputy general director of the Vietnam national television station. On 16 March 2015, he filed a letter to Chairman of the Hanoi People's Committee (aka. the city government), Nguyen The Thao, in which he requested a suspension to the tree felling so that citizens could justify whether 6700 trees were subject to being replaced. Mr. Tuan's letter went viral on both Facebook and mainstream media since during that time the state media had not been asked to "shut up". The kick-off letter by Mr. Tuan set the course for the movement, which was timely followed by the initiatives and actions of the Group 6700 People, the pathbreakers of the movement.

\section{Group 6700 People}

Following Mr. Tuan's letter was the prompt emergence of the Facebook page "6700 people for 6700 trees" established by a housewife with first-hand experience in social activism. The aim of the page was initially simply to seek 6700 LIKES to pay tribute to the felled-, and going-to-be-felled trees. The page was shared on a grand scale; it received 10,000 LIKES just within $24 \mathrm{~h}$ and over 60,000 LIKES within 2 weeks. From this fan page, Group 6700 People emerged as a pioneering group of the TM and took on the role of managing the fan page (the group communication and discussion was mainly via Facebook). This Facebook group was set on 'closed status' for safety reasons, including roughly 100 members coming from diverse backgrounds, namely, human rights experts, social activists, journalists, IT specialists, scientists, local NGO leaders and staff, researchers, lawyers, architectures, lecturers, artists, and etc. It was a closed group; therefore, if anyone wanted to join it, he or she needed to be introduced by a standing member. The group was horizontally organized and loosely structured with no presence of a single, identifiable leader taking dominance. It is to clarify that the communication and discussion within the group members was mainly via this Facebook group, but this group used the fan page "6700 People for 6700 Trees" to communicate with the public, to mobilize wider support, and to call for collective action.

Noticeable about this group was the core team which included a small number of people, mostly being leaders of registered local NGOs and independent local experts, who had been previously working together in several projects. A certain degree of trust and mutual understanding already existed between them when they embarked on Group 6700 People. They are professional, knowledgeable, dedicated and especially activist-oriented. Their togetherness was based on their shared concerns and objectives towards saving the trees. The role of this core team was pivotal because they functioned as the steering committee, being the actors who created and decided mobilizing structures and repertoire of actions at the backstage.

The outnumbered members from registered local NGOs and the minimal presence of pro-democracy activists were indicative of their mode of activism, i.e. mildness and non-confrontation. Nonviolence and collaborative spirit was the backbone of their activism, as an administrator of the group stated "We are not 
agitators, we only strive to show to the government our good will to cooperate, not to confront".

Being controlled by the state through registration, local NGOs in Vietnam have to seek refuge in non-confrontation and self-imposed censorship for their actions. However, their mild manner, as we will see later in this paper, does not mean that their activist orientation is dismissed but rather they were strategic, timely, and dynamic in their activism. Their strategic thinking were seen in several respects, for example, through the vocabulary they used in the influential Petition they initiated, the efforts to set up meetings with the city government to address the Petition, the way they framed the issue to make it reach out to a wider population and mobilize wider participation, and the way they appealed to the available formal channels (i.e. the Constitution, the relevant state legal documents, etc.) to claim legitimacy for their acts.

The first collective effort of the path-breaking Group 6700 People was to set up a dialogue between people and authorities and request transparency concerning the project be put in place. The first group meeting was quickly initiated by a local independent expert on human rights and took place on 17 March 2015 at the office of a proclaimed local NGO one day after the fan page was established. This meeting played a crucial role in setting the course of the group action as well as strategizing actions for the campaign during early stage. Around twenty people attended this meeting, in which apart from the core team of 5-6 people, the rest had not known each other before. Quynh Lam, a member of core team, stated as follows:

In this meeting, although the majority had not known each other before, the discussion flow was smooth and no conflict occurred. Perhaps it is because the trees issue was so urgent that no one tried to take it personally. Looking at the movement as a whole, it was a loosely organized movement, generally speaking. Its structure looks like a school of fish for there is no single leader taking a lead. (Interview, 07 April 2015, Hanoi).

There was only a facilitator who was a leader of a local NGO ensuring the flow of the meeting. Labour division was based on individuals' voluntariness and expertise, with no one giving command or order. Five themes of action were quickly agreed on namely: (1) Information gathering: data, evidence from all sources; (2) Communication: working closely with mainstream media as long as they are still allowed to voice up, liaising with scientists and experts to collect scientific evidence, working with lawyers to mobilize their legal support; (3) Advocacy: searching for any influential contact within the state who can help set up a meeting with Hanoi authorities if possible; (4) Petition signing: collecting public signatures for the petition and addressing it to the city government; (5) Event organizing: Tree Hugs Picnic (cum public demonstration).

The sequence of actions in their mobilizing structure above is noticeable because this is indicative of their strategic activism. Specifically, public protest (i.e. Tree Hugs Picnic) was not the FIRST action that they mobilized collective to undertake. Instead, this action would come after the efforts of establishing dialogue and petition signing. Although they constantly received numerous comments on the fan page urging them to wage a protest, they were resolute and persistent with their 
action agenda. Not being provoked by the radical ideas to take to the streets, they sought to set up a dialogue with the city authorities in the first place.

After the agreement on labour divisions was reached at the backstage, they circulated this action agenda on the fan page to mobilize support and participation. It is to notify again that during the beginning period, Group 6700 People was central to the civic-led campaign, tens of thousands of Hanoians followed their Fan page. The first important action they focused on was to mobilize public support for the Petition signing:

It is not our hatred but our love which can save our city. Instead of sitting still and showing our resentment to the city government, let's take action to save our city.

(Quoted from on “6700 people for 6700 trees” page, dated 18 March 2015).

The urgency, professionalism, and efficacy in their mobilizing structure were noticeable. Tree after tree was cut down without hesitation from the authorities; the course of actions was therefore to be calculated with maximized effects but within the shortest period of time. Shortly after the first group meeting on the 17 March, without any delay, the citizens' petition was thoughtfully drafted in both English and Vietnamese and posted on the Fan page to collect signatures. On 19 March 2015, with less than $24 \mathrm{~h}$, the group collected 22,000 signatures for the petition. On the morning of 20 March 2015, three small groups of 5-7 people/each were mobilized with the participation mainly from their closed group turned up at the related city government offices to address the Petition in person. This was the first time a civic action as such emerged, i.e. a group of civilians transcending their fear, aware of their citizenship rights, taking action for the sake of the wider community and turned up at the offices of the power holders to request a direct meeting and hand in publics' petition. The decision to meet up with the city authorities in person to address the petition rather than sending via post was strategic and also showed their determination in setting up a collaborative dialogue with the government.

The efforts of Group 6700 People to establish dialogue with the government to some extent bore fruit, which could be seen in the government decision to put the tree-cutting project on hold. In coping with the escalating public pressures, the President of the Hanoi People's Committee finally decided to temporarily suspend the project on the afternoon of the 20 March 2015, after the Group handed in the Petition on the morning of the same day. However, this response was simply a cosmetic tactic of the city administration and far from satisfactory for innumerable public questions related to the project which were unanswered by the government, for example, its sources of budget, the timber of the felled trees, responsibilities of relevant officials, etc. Particularly, the halt of the tree cutting was only the first among the three objectives stated in the Petition to Hanoi authorities, the rest concerning 'openness' and 'accountability' had yet to be met.

Against this backdrop, the Group 6700 People decided to move to the next step of their mobilizing structure, i.e. taking to the streets in the form of a "Tree Hugs Picnic" (cum public demonstration) in order to realize the remaining objectives. The picnic was staged on 22nd March 2015, two days after the Hanoi government's decision. The event was widely covered on mainstream and social media and drew 
participants from all walks of life. Around 500 people came from diverse segments of society joined the picnic, many of whom wore advocacy T-shirts (sponsored by a local NGO), carried Tree Hugs Hanoi banners, holding hands outside the park and displaying their love for Hanoi, love for environment and love for trees. They sang, played music, hugged trees and marched along the lake, calling to stop the fell of trees and protect environment. The picnic was covered with the atmosphere of friendliness, peace, and love, which was the leading message that the Group 6700 People strived to spread to publics. The event happened with no excessive behaviour from security. The civic activism by the pioneering Group 6700 People, as an active activist of the Green Hanoi Group revealed, played an important role in helping the movement avoid state repression from the start.

In the aftermath of the Tree Hugs Picnic, the state intolerance started to accelerate, i.e. several members of the closed group received the warning of the police, many students who participated in the picnic or simply wanted to stick posters or ribbons to the trees were asked to go the police station for interrogation, mainstream media was asked to stop all writings concerning the tree project, the propagation brigades were mobilized at all neighbourhoods, etc. (how the state responded to the TM will be discussed in more detail later on). Given this, the Group 6700 People gradually diminished its activism, moving from the forefront at the beginning period of the movement to the margin at the later stage. After the Picnic (also considered the first street protest of the movement), the group put brake on mobilizing public demonstration, but they continued to make efforts to seek opportunities to work with government agencies, for example, they continued to find a contact in the state apparatus that was willing to help them have a meeting with the city government leaders. However, the authorities became more intolerant and their efforts were again unsuccessful.

It is notable that the Group 6700 People were largely crystallized by registered local NGO participation, those controlled by the state via registration. Although they participated in the movement in terms of their personal capacities and activistorientedness not on behalf of their organizations, this does not mean that the survival of their organization was not at risk. However, their calculation of the opportunity structures opened avenue for them to take an informed risk, which implied that conceiving the contention inherent in the movement but they learned that the repertoire of actions they were employing was lawful and rightful. Therefore, appealing to the approved formal channels kept them not to break the fence or tread the legal bound.

\section{Group 6700 Trees}

Entering the fray a bit later than Group 6700 People was Group 6700 Trees. The group was established by two architects, who had first-hand social activist experience, on 18 March 2015, one day after the former. Differentiated from the former who communicated with publics through the Fan page, the latter had no fan page and was set up as a 'Public Group', owing to which it allowed for a direct communication between group members, and made administrators of the Group visible to everyone. The emergence of the group also had the same repercussion as 
its predecessor. Within $24 \mathrm{~h}$, it enrolled 4300 members, and new posts about tree felling were updated every second. The two architects initially set up the group with an aim to mobilize publics' contribution of images and video clips of Hanoi trees, which would be used as invaluable inputs for the development of 1-h documentary about the love and response of Hanoians to the loss of their trees.

The purpose of the movie was to accurately reflect the impacts of the tree-felling project upon the city residents and the need for community participation in urban development management. The message the movie wished to convey was "City for People", or "Do Thi Vi Nhan Sinh", which emphasized on humane values in architectural and urban spaces (Vietnamnews 2015).

On 29 March 2015 after the "Green Walk for Trees", also the unique street protest was orchestrated by this group, which drew roughly 800-1000 participants. This event echoed a substantial repercussion for the TM, because it pushed the state intolerance to a new level. After the Green Walk, the group administrators encountered the surveillance and harassment by security forces, specifically two group founders were asked to show up at one of high-level security agencies of the Ministry of Public Security for interrogation meanwhile other administrators had to receive unexpected visit by security officers at their private residences. Under such high pressure, all the notes related to the Green Walk and calls for subsequent public protests were asked to be deleted; the Facebook group was set from public to closed status; some administrators had to quit and others had to declare on the page that there would be no mobilization for any more public demonstration onwards. This declaration disappointed radical minds in the group, those who sensed that the group had been severely interfered by public security; they therefore decided to divorce from Group 6700 Trees and set up a new Facebook group "For a Green Hanoi" on 31 March 2015. The Group 6700 Trees gradually demobilized after the Green Walk and restricted its activism to the investigation of legal documents regarding this tree-felling project.

\section{Group Green Hanoi}

Since its emergence, Group for a Green Hanoi (called Green Hanoi hereinafter) resumed activism by taking a leading role in the movement when the other groups diminished. They pursued various acts of resistance including public demonstrations, civil disobedience and using legal means. Their activism was aimed to demand the municipal government to be accountable and to sanction-related individuals who committed wrongdoings. The group attracted more than 9000 members coming from most societal segments. Like the organizational structure of preceding groups, the role of a single leader was absent, instead the key members who made up the core team of the group decided what direction to go; hence, the role of key members and administrators became salient.

Distinctive about the group composition was the engagement of independent activists who particularly acquired street protest experience from dozens of previous anti-China demonstrations, thus their preparedness to tread the limit of permissibility was more discernible. These independent activists are critical of regime and exercise their contention through their writings on their blogs, Facebook pages and 
taking to the streets. Their activist experience helped them transcend the emotion of fear and placed them in pioneering positions in a series of public protests waged by Green Hanoi Group. The core team of the group included not only experienced activists but also new comers (i.e. inexperienced and young activists). One of the group administrators stated as follows:

A key reason for our persistent efforts to sustain the campaign despite the increasing repression is to empower people, to familiarize them with resisting, opposing inappropriate state policies and decisions rather than seeking refuge in silence and passiveness. This may be considered as a small step but holds significance in Vietnam now where people choose to be indifferent to politics for fear and/or lack of confidence. (Interview, 30 April 2015, Hanoi).

Since its emergence, the group continued to wage more public protests and events including marching, biking, filing open letter and complaint to the city government. They shifted to using legal means for expression of opposition rather than staging more public demonstrations only after being harassed and repressed heavily. They filed two open letters and addressed them to the city authorities in person to show their determination in requesting an accountable government. A group member, a new activist, stated that "People should not be discouraged from taking action by the mindset that nothing can be changed. Our small action might set a small brick on the way, but it will make a difference in the long run if we persist".

There was a critical difference in the objectives of activism between Group 6700 People and Group Green Hanoi. While asking for sanction and prosecution of those who committed wrongdoings was absent in the set of goals to be achieved by the former, it was brought onto the latter's action agenda. With historical activist experience, the concerted efforts of the Group Green Hanoi were aimed to reach more ambitious goals that explicitly challenged the state legitimacy. They strategically adjusted their methods of struggle in association with the state response.

A series of public demonstrations were orchestrated by Group Green Hanoi on four consecutive Sundays which were accompanied with varying degrees of state interventions ranging from house watch, harassment, detainment, violent assault and stigmatization of private lives of a number of group members. The appearance of five to seven plainclothes security officers from the early morning in front of the group activists' houses to intimidate and prevent them from attending the rallies was common. Because of this, many of them had to sneak out from their homes on the night before or a couple of days in advance to avoid security detection so that they could join the protests. Particularly, one of the group administrators, also a blogger, was violently assaulted by plainclothes police on 22 April 2015, which caused the group to add issues of violence and police harassment to the struggle objectives aside from tree saving and government accountability. The assault was aimed to threaten the group and publics as a whole from staging more protests but it had reverse effects. The Green Hanoi group continued to take to the streets on 26 April 2015; this was the final street protest of the group when they were heavily repressed by hundreds of police officers and civic order defenders. 
There are some salient points pertaining to the group's final protest which needs to be pinpointed. Amid the escalating state aggressiveness, sensing a high possibility of state repression in the coming demonstration, they strategically mobilized new faces of the group, most of whom were young females, to wear traditional long dress 'AO DAI' to stand in the front line of the march. The image of young women in traditional long dresses juxtaposed with the aggressiveness of security forces, they expected, could to some extent help the campaigners avoid state violence. But things did not happen in that way. These women together with other protesters were suppressed by hundreds of police and civic order defenders. Twenty two people were arrested in total in the street demonstration on the 26 April 2015 and were accused of causing public disorder. Salient to this critical suppression was the courage and solidary spirit of experienced activists when they tried to accompany the newcomers to the police station though they were not among targets of arrest.

So far I have provided an insightful account of each TM group and examined how they emerged, how they were structured and organized, and how and why they embarked on certain repertoire of actions at certain period of the TM. The advancement and demobilization of each group was contingent on how it was characterized. In what follows, I will bring more insight into the mobilization process of the TM, specifically how the TM mobilized people and provoked them to act. Concurrently, I will shed light into how the Group 6700 People (i.e. registered NGO-based) and Green Hanoi Group (i.e. independent activist-based) engaged in a so-called surreptitious symbiosis at the early period of the TM. Underscoring this analysis is also my attempt to elucidate how environmental issues were articulated by the tree campaigners to encroach on political activism such as good governance and government accountability.

\section{Environmental Activism: A New Arena of Contestation}

Under the unexpected pressure of civic opposition, the city government had to retreat by suspending the project and promised to review it. This U-turn state response to public criticism seems still rare in one-party Vietnam albeit an increasing sign observed in recent times. As a matter of fact, political criticism is unabatedly treated as a sensitive or 'forbidden' terrain under a handful of deterring tactics employed by the state (such as arrest and jail of some distinguished critics). Nonetheless, trees or environmental issues in broader sense, apolitical issues on the surface, have opened a new avenue for civilians in such authoritarian regimes as Vietnam to exercise contestation. In Vietnam, politics is often treated not 'everyday' or 'petty' politics (i.e. politics with small p) but instead as anything that the Communist party thinks might challenge its monopoly of power (politics with big P) such as regime change, calling for multi-partyism or pluralism, or independent labour union.

In analysis of this civilian-led movement, I argue that it will be missing much if the TM is treated strictly as environmental activism because environmental issues were tactically articulated by the TM campaigners together with political issues 
such as good governance and government accountability into their mobilizing structures. This was evidenced in the fact that though the halt to the tree cutting was in place, it failed to make Hanoians satisfied for the myriad of questions related to the transparency of the project and accountability of the city administration were not answered. As a result, the campaign proceeded even with stronger actions.

As stated on the page of the Group Green Hanoi:

[...] and our actions are not only limited to calling for the halt of tree felling or requesting government transparency in very general terms. We need to create a precedence, i.e. the government must be accountable for its wrongdoings. Those who misconduct must be sanctioned. Public property once destroyed, the community must be compensated. We, citizens, are entitled to demanding a transparent and accountable government, and we can do it. Demonstrations or green biking are only one component of our action agenda which step by step aims to promote a transparent and responsible government. (Excerpted from the Facebook page Green Hanoi dated 16 April, 2015).

The dynamic of the TM rests on the fact that: from the façade, it emerged as loosely structured, clandestine and non-hierarchical. However, beneath it was wellorganized and professionalized. A repertoire of nonviolent actions appealing to both formal and informal channels were mobilized to demand an immediate halt to the felling ranging from changing profile pictures, sharing photos and videos on Facebook, petition signing, setting up official meetings with the city government, beautifying trees with ribbons, trees mapping, organizing workshop and especially taking to the streets.

In the first place, to claim legitimacy for their rightful resistance, throughout the movement the tree campaigners appealed to the fundamental citizenship rights stated in the Constitution and nested within state agenda and discourse:

We have formed our requests based on our good will to cooperate with Hanoi authorities in the implementation of the 2013 Constitution, specifically of the right to access information, the right to participate into state and social management, as well as the corresponding obligation of the State (Chapter II, Article 25 and Article 28), the Environmental Protection Law and Ordinance No. 34/2007/PL-UBTVQH11 on Implementation of Democracy in Wards, Communes, and Townships. (Excerpt from the Petition of the Fan page 6700 people for 6700 trees).

By careful appeal to the Constitution and other related legal documents (i.e. formal channels) in the Petition, the first civic action of the TM staged by the pioneering group 6700 People, the campaigners of this group showed their professionalism and signalled a clear message to the city administration that "we are aware of our constitutional rights but importantly we are not in position of confrontation but cooperation".

The TM groups were committed to nonviolence, and in their endeavours, they established a civil resistance model in which civilians knew, spoke out, and exercised their rights in a peaceful and rightful manner. The reason why the TM had to bring the idea 'nonviolence' and 'rightfulness' to the forefront from the start was 
plausible. In the non-democratic regimes like Vietnam where public fear is still prevailing because of the state coercion, the tree campaigners understand that general fear should be mitigated as a first step in the mobilization process. Once fear is mitigated, it would attract more participation, which provides a potential protection for individual participants.

Fear was tactically mitigated and transformed by the TM groups through a repertoire of strategic actions. First, the vocabulary they used conveyed the severity, urgency, efficacy and propriety. Their attempts were to break down a fine line between inside-outside participants of the movement. They encouraged people not to fear by repeatedly reiterating that "it is absolutely our constitutional rights to voice our concern" or by delivering an appealing message to spark people's consciousness and conscience to accelerate collective mobilization:

[...] we have to raise our voice so that there will be no more environmental destruction like this in the time to come. We are not those who try to hinder human advancement. What all we require is transparency, consultation, and respect. Nature needs also to be respected. (Excerpted from Fan page 6700 people for 6700 trees, 18 March 2015).

The second strategy the campaigners used to mitigate public fear to trigger collective mobilization rests on their publicly stated determination to protect participants and their efforts to promote solidarity among participants. In company with the growing dynamics of the movement was the increasing harassment by security forces, especially young students being targeted most. Amid the increasing complexity of the movement, the mobilizing groups created a self-protection mechanism for participants by improving their legal awareness. They mobilized legal support from lawyers who were willing to help and to become a part of the movement. The guiding information regarding each specific harassment case was carefully explained on the groups' pages so that people could know about their rights and in which case their rights were being violated.

The group Green Hanoi, with the presence of several independent activists who were experienced in street activism, designed a detailed but easy to understand handbook titled "How to work with security forces and universities" for the young participants in the TM. This guidance document provided basic and useful information to improve awareness and capacities of the young people on how to behave and respond when being exposed to work with the public security and/or being questioned by their universities. Tactics, essential legal knowledge, and simulation scenarios in which the youth might face with were thoroughly presented. This document became a common asset for the tree campaigners.

Throughout the course of the TM, there was a phenomenon which was for the first time observed in civil society activism in Vietnam, i.e. the below-the-radar cooperation between the registered NGOs and independent activists (IAs). One might question whether there was any kind of symbiotic relationship between the TM groups, whether the registered NGOs and independent activists worked together in the TM? Theoretically, searching for evidence of the so-called cooperation of any level between registered NGOs and IAs/dissidents who are branded as reactionary and hostile forces by the state seems barking up the wrong tree. If it exists, as many 
of my respondents revealed, it is basically based on the personal relationship between NGO leaders and IAs not on behalf of their organizations, and in most cases, they are kept in confidentiality. An experienced independent activist explained why it was so:

It is difficult to reach a cooperation between the two. That is because trust matters. When trust is not established, almost nothing can be done. Independent activists/dissidents in the eyes of the ruling communists are named with the labels which seem frightening to most of populace such as hostile forces or reactionary forces. Whereas the registered NGOs constrained by the registration have to position themselves away from confrontational methods. Given their conditions and relations with the government and donors, being too close to the IAs who are critical of the regime could put them at risk. It was also uneasy for them to establish collaborative relationship with 'reactionary forces' since security agents will not leave them in peace. (Interview, 10 June 2015, Hanoi).

However, there was a good sign observed in the TM, and also the unique phenomenon since for the first time between the registered NGOs and independent activists emerged a sort of common voice over a common issue. The below-theradar coalition between them is subtle but significant. What actually happened between the two groups? Why did the group of IAs, Who were experienced in activism, not organize public demonstration from the start? Why was the first street demonstration (i.e. Tree Hugs Picnic) orchestrated by Group 6700 People, not by IAs?

It was observed that when public rage reached climax, a possibility of public protest was apparent, but it did not happen at that period of time. If it had happened with the presence of IAs, all efforts to set up dialogue with the government could have failed, and even worse the TM might have encountered state crackdown from the start and 6708 trees as indicated in the project could have completely cut down. As a matter of fact, the state never wants to have dialogue with the IAs, no matter what the issue is. Aware of this, the Group 6700 People, through an intermediary who was an independent writer, sent an important message to the IAs group in an attempt to explain the situation and seek their endorsement, in which they persuaded the IAs not to take to the streets too soon because they were trying to establish an official dialogue with the city government. As a result, public protest only happened at the moment when it was supposed to be appropriate. Needless to say success in curbing public protests not to happen too soon was the credit of the Group 6700 People and also the IAs.

The IAs understand that for any social campaign or movement the participation base needs to be enlarged; new faces are necessarily mobilized to bring new energy for civic activism. In the Tree Hugs Picnic, some prominent IAs turned up at the rally but played role of supporters not leading actors. In essence, the two groups established a mutual respect and understanding of their own strategies, methods and positions. Throughout the movement whenever possible they shared information to find a niche for any opportunity that they could provide support to each other. The mutual respect and below-the-radar cooperation albeit subtle between the groups 
emerged as an unprecedented phenomenon signalling a good sign for civil society activism in Vietnam.

If Group Green Hanoi (IA-based) showed their support to Group 6700 People (i. e. NGO-based) by staying in the background at the beginning, the latter also showed their support in return. The seminar (i.e. formal channel) titled "From the Project 6700 trees to Hanoi planning issues" which was co-organized by two local NGOs on 23 March 2015, was open to everyone including IAs. Attended by popular experts, lawyers and scientists, the seminar was aimed at receiving opinions from scientists and experts and conveying them to the public and media. Most participants raised a shared concern that the project violated the 2012 Law on the capital city and the government's Decree 64/2010/ND-CP on the management of urban trees, and they demanded that the investigation be deployed with the involvement of the Central government Inspectorate. Explaining the significance of this seminar, an experienced democracy activist of Group Green Hanoi indicated "This was an important event since it provided us with plenty of valued information that was useful for the legal struggles of our group in the subsequent stages."

In addition, the Group 6700 People also raised their voice timely to show their solidarity with Group Green Hanoi when a human rights activist also a prominent member of the latter was allegedly assaulted by the regime thugs. The image of his face covered with blood went viral on social media sites exacerbating public indignation and haunting those with conscious minds. A nonviolent action of civil disobedience was taken, i.e. hundreds of Vietnamese facebookers inside and outside of the country changed their avatars to his bloody face to show their resentment to the authorities and their solidarity to the activist. At that time, the government's public opinion shapers (rumour-mongers), one part of regime propaganda brigade, tried to provoke Group 6700 People to suspect and stay away from the Group Green Hanoi for it being driven by reactionary actors. In response to this, the former showed its timely support to the IA group on its Facebook page by exposing the instrument effectively used by the pro-communist agenda to isolate the IAs from the general populace, i.e. labelling arbitrarily anyone who was critical of the ruling power as reactionary or hostile forces. Walking over fear to openly show their sympathy and solidarity with the Group Green Hanoi, this act by Group 6700 People was appreciated by the IAs.

In brief, the TM started out as an environmental campaign but as it evolved the tree campaigners managed to stage contentious acts under this rhetoric and caused the government to respond accordingly. The ebb and flow of each group was contingent on how it was institutionally characterized. Each group in the TM has certain roles to play, none of which should be downplayed. Different groups emerged, converged and then diverged. While Group 6700 People was the pathbreaker of the movement then diminished after the Tree Hugs Picnic because of the increasing state interference, Group Green Hanoi was the successor and continued to bring the campaign forward. Although Group 6700 Trees no longer initiated any further public demonstrations, it focused its activism on tracing drawbacks of the tree-cutting project in terms of legal aspect (Fig. 4). 


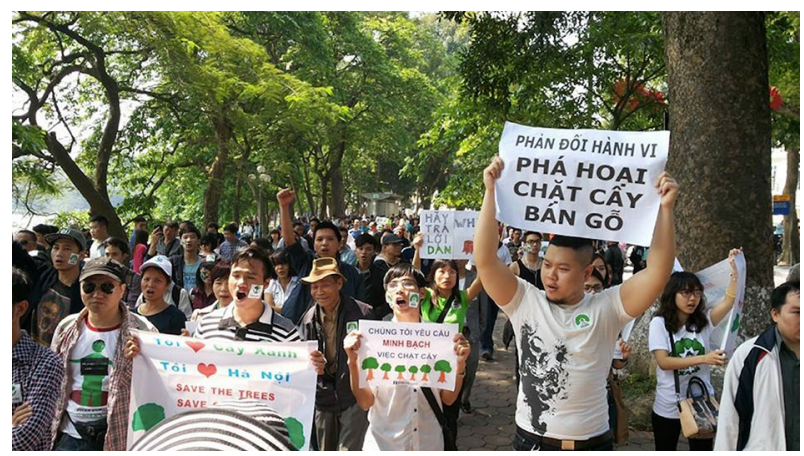

Fig. 4 Peaceful demonstration at the lake. Source from Facebook page of Group Green Hanoi

\section{Conclusion}

At first glance, the TM came across as a localized aesthetic issue: people liked the trees and were upset because the government decided to cut them down with no public consultation. Yet the TM, I have argued, is far more political than meets the eye. What started out as a localized campaign evolved into a movement through which people made demands for a form of governance that is accountable, deliberative and respectful of its citizens. The aim of concerted efforts in the TM is to gradually create a habit of exercising democratic culture through advocating voice and action over silence and passiveness. In a politically restricted environment where public disrespect by the authorities is prevalent and where fundamental human rights such as freedom of speech, association and assembly are routinely violated, the TM activism signals that when people leaving fear behind stand up to the government, change is possible. That change might be just a small victory on the way but over the long run with sustained efforts substantive change can emerge. As Goldfarb (2007, p. 1) proclaimed, "Political change doesn't always begin with a bang; it often starts with just a whisper".

This paper has argued at the beginning that grassroots citizen-led activism, an emerging form of civic engagement, is likely to play a critical role in (re)shaping state-society relations in Vietnam. Throughout my analysis, I attempted to illustrate this argument. I managed to portray how Hanoi citizens orchestrated rightful civic actions to oppose the unpopular state decision in cutting down healthy old trees. This form of activism, if sustained, could encourage a move toward more deliberative and accountable politics in Vietnam in the long run. The TM highlights three points regarding the civic mobilization and especially local grassroots activism that has been understudied in the existing literature on Vietnamese civil society.

First, environmental activism has opened up a new arena of contestation for civil society activism in Vietnam. Amid unpredicted and uncertain state intolerance, political criticism is repeatedly treated as a sensitive or 'forbidden' terrain under handful of deterring tactics employed by the state. Nonetheless trees or environmental issues, apolitical from the façade, open a new avenue for civilians in 
authoritarian Vietnam to exercise contestation advocating their rights and demanding a more accountable government.

Second, The TM is a broad coalition bringing together organized groups such as NGOs with unorganized groups of independent activists. This type of coalition is new in Vietnam and has triggered a more tolerant response from the state as well as created opportunities for further civic actions. This was the first time where the registered group (NGOs) and unregistered group (independent activists) reached a common voice about a single issue, and importantly, they established some sort of a mutual arrangement or negotiation in sustaining activism. The below-the-radar cooperation between them was subtle; however, it was still significant in that it helped the movement circumvent the early state intervention. As a result, the prolonged period of the movement created a good opportunity for enhanced civil society actions to challenge the state authority.

Third, the TM gives a signal to the political elites about how people power can respond to state arbitrary decisions which directly affect their daily lives. Specifically, it informs the government of how civilians can react and organize rightful civic actions to oppose unpopular state decisions and policies. In the era of the digital technology, the single-party-ruled state can control and silence the staterun media but fails to do so with social media where citizen journalism is blooming with open criticism and dissent towards the government. Social media was used effectively by the TM groups to orchestrate collective actions and especially to empower people and raise their awareness of their citizenship rights. Castells (2012) once argued that political change, in order to be in place, needs to come from the change in the minds of the people. Castel's argument rings well with what most of respondent accounts from both NGOs staff and activists toward the TM. The mobilizing groups incorporated constitutional rights in their mobilizing structures, on one hand to claim legitimacy for their activism and to improve public awareness of their citizenship rights on the other.

In the view of NGOs, creating a paradigm shift is beyond the ability of TM, and acknowledging the movement as the glorious victory of civic resistance is absolutely misleading. They are more inclined to recognizing it as a test for civil society's capacity to stand up to the state, and an incubator for more organized civilled activism. Meanwhile for the activists, the grassroots TM gives a sign of people power that activated citizens aware of their agency come to organize themselves and demand government accountability. This phenomenon is still seen rare under the authoritarian constraint of Vietnam.

Acknowledgements I would like to thank all my respondents in Vietnam who believed in me and shared with me their stories. I especially thank Joe Devine, Oliver Walton, Adam Fforde and the anonymous reviewers for their valuable comments and suggestions on earlier drafts of this article.

Funding This article is one part of my Ph.D. research. I have received full scholarship for my Ph.D. research from University of Bath, UK. The name of the scholarship: 50th Anniversary Excellence Studentships for Overseas Students. Sponsor license number of this scholarship: C2DENCHXO. 


\section{Compliance with Ethical Standards}

Conflict of interest The author declares that there is no conflict of interest under any circumstances.

Open Access This article is distributed under the terms of the Creative Commons Attribution 4.0 International License (http://creativecommons.org/licenses/by/4.0/), which permits unrestricted use, distribution, and reproduction in any medium, provided you give appropriate credit to the original author(s) and the source, provide a link to the Creative Commons license, and indicate if changes were made.

\section{References}

Brown, G. K. (2004). Civil society and social movements in an ethnically divided society: The case of Malaysia, 1981-2001. University of Nottingham.

Bui, T. C. (2005). Các tổ chức xã hội Việt Nam. Xã hội học, số 2 (90), 2005

Bui, T. H. (2013). Liberal constitutionalism and the socialist state in an era of globalisation: An inquiry into Vietnam's constitutional discourse and power structures. The Global Studies Journal, 5(2), 4354.

Castells, M. (2012). Networks of outrage and hope: Social movements in the Internet age. Chichester: Wiley.

Cavatorta, F. (2012). Civil society activism under authoritarian rule: A comparative perspective. London: Routledge.

Chandhoke, N. (1995). State and civil society: Explorations in political theory. New Delhi: Sage Publications.

Cheskin, A., \& March, L. (2015). State-society relations in contemporary Russia: New forms of political and social contention. East European Politics, 31(3), 261-273.

Devine, J. (1999). One foot in each boot: The macro politics and micro sociology of NGOs in Bangladesh. Doctoral dissertation, University of Bath.

Fontana, B. (2002). Gramsci on politics and state. Journal of Classical Sociology, 2(2), 157-178.

Glasius, M., \& Ishkanian, A. (2014). Surreptitious symbiosis: Engagement between activists and NGOs. VOLUNTAS: International Journal of Voluntary and Nonprofit Organizations, 26, 1-25.

Goldfarb, J. C. (2007). The politics of small things: The power of the powerless in dark times. Chicago: University of Chicago Press.

Goodwin, J., \& Jasper, J. M. (2004). Rethinking social movements: Structure, meaning, and emotion. Lanham: Rowman \& Littlefield.

Gray, M. L. (2015). Control and dissent in Vietnam's online world. TIASANG Vietnam Research Report. http://secdev-foundation.org/wp-content/uploads/2015/02/Vietnam.ControlandDissent.Feb15.pdf.

Hannah, J. (2007). Local non-government organizations in Vietnam: development, civil society and statesociety relations. Seattle: University of Washington.

Hoffmann, B. (2011). Civil society 2.0? How the Internet changes state-society relations in authoritarian regimes: The case of Cuba.

Johnston, H., \& Carnesecca, C. (2014). Fear management in contemporary anti-authoritarian oppositions. In D. Chabanet \& F. Royall (Eds.), From silence to protest: International perspectives on weakly resourced groups. Ashgate Publishing, Ltd.

Kerkvliet, B. J. T. (2010). Workers' protests in contemporary Vietnam (with some comparisons to those in the pre-1975 south). Journal of Vietnamese Studies, 5(1), 162-204.

Kerkvliet, B. J. T. (2014a). Government repression and toleration of dissidents in contemporary Vietnam. Politics in Contemporary Vietnam (pp. 100-134). London: Springer.

Kerkvliet, B. J. T. (2014b). Protests over land in Vietnam. Journal of Vietnamese Studies, 9(3), 19-54.

Kerkvliet, B. J., Nguyen, A. \& Bach, S. (2008). Forms of engagement between state agencies and Civil Society Organizations in Vietnam. Retrieved September 12, 2009 from http://www.ngocentre.org. vn/files/docs/Forms_of_Engagement_FINAL_COMPLETE.pdf.

Landau, I. (2008). Law and civil society in Cambodia and Vietnam: A gramscian perspective. Journal of Contemporary Asia, 38(2), 244-258. 
Le, Q. B., Doan, T. H., Nguyen, T. T. N., \& Mai, T. T. (2016). Báo cáo phong trào bảo vệ 6700 cây xanh ở Hà Nội. http://isee.org.vn/Content/Home/Library/473/bao-cao-phong-trao-6700-bao-ve-cay-xanho-ha-noi..pdf.

Lotan, G., Graeff, E., Ananny, M., Gaffney, D., \& Pearce, I. (2011). The Arab Spring: The revolutions were tweeted: Information flows during the 2011 Tunisian and Egyptian revolutions. International Journal of Communication, 5, 31.

McAdam, D. (2010). Political process and the development of black insurgency, 1930-1970. Chicago: University of Chicago Press.

McCarthy, J. D., \& Zald, M. N. (1977). Resource mobilization and social movements: A partial theory. American Journal of Sociology, 82, 1212-1241.

Morris-Jung, J. (2015). Vietnam's online petition movement. Southeast Asian Affairs, 2015(1), 402-415.

Norlund, I. (2007). Civil society in Vietnam. Social organisations and approaches to new concepts. Asien, 105, 68-90.

Ramasamy, P. (2004). Civil society in Malaysia. Civil Society in Southeast Asia (p. 198). Singapore: Institute of Southeast Asian Studies.

RFI. (2015). Cây xanh làm thức tỉnh xã họi dân sự. http://vi.rfi.fr/viet-nam/20150406-cay-xanh-lam-thuctinh-xa-hoi-dan-su. Accessed 6 April 2015.

Sinh, B. T. (2003). Civil society and NGOs in Vietnam: Some initial thoughts on developments and obstacles. In: Paper presented at the meeting with the delegation of the Swedish Parliamentary Commission on Swedish Policy for Global Development to Vietnam, p. 2002.

Sinh, B. T. (2011). Civil society in Vietnam. In T. Chong \& S. Elies (Eds.), An ASEAN community for all: Exploring the scope for civil society engagement (pp. 138-147). Copenhagen: ISEAS and NIAS Press.

Smith, C. (2011). Egypt's Facebook revolution: Wael Ghonim thanks the social network. The Huffington Post, p. 11.

Tarrow, S. (1994). Power in movement: Social movements, collective action and mass politics in the modern state. Cambridge: Cambridge University Press.

Teets, J. C. (2014). Civil society under authoritarianism: The China model. Cambridge: Cambridge University Press.

Thanh Nien News. (2015). People see red as Hanoi starts cutting down 6,700 trees. http://www. thanhniennews.com/society/people-see-red-as-hanoi-starts-cutting-down-6700-trees-40014.html. Accessed 19 Mar 2015.

Thayer, C. A. (2009). Vietnam and the challenge of political civil society. Contemporary Southeast Asia: A Journal of International and Strategic Affairs, 31(1), 1-27.

Tilly, C., \& Tarrow, S. G. (2015). Contentious politics. Oxford: Oxford University Press.

Wells-Dang, A. (2010). Political space in Vietnam: A view from the 'rice-roots'. The Pacific Review, 23 (1), 93-112.

Wells-Dang, A. (2011). Informal pathbreakers: Civil society network in Vietnam and China. Doctor of Philosophy, University of Birmingham

Wischermann, J. (2003). Vietnam in the era of doi moi: Issue-oriented organizations and their relationship to the government. Asian Survey, 43(6), 867-889.

Wischermann, J., 2013. Civic organizations in Vietnam's one-party state: Supporters of authoritarian rule?

Vietnam News. (2015). "Tree-felling fiasco: symptom of a deep-rooted problem" by Thu Huong Le. Retrieved March 26, 2015 from http://vietnamnews.vn/opinion/op-ed/268085/tree-felling-fiascosymptom-of-a-deep-rooted-problem.html.

Vietnam News. (2015). Tree huggers inspire new documentary. Retrieved April 7, 2015 from http:// vietnamnews.vn/life-style/268694/tree-huggers-inspire-new-documentary.html.

Vietnamnet. (2015). Chặt cây xanh Hà Nội không phải hỏi dân. Retrieved March 17, 2015 from http:// vietnamnet.vn/vn/chinh-tri/226164/-chat-cay-xanh-ha-noi-khong-phai-hoi-dan-.html.

Vietnamnet. (2015). Chặt 6.700 cây: Đề nghị thanh tra Chính phủ vào cuộc. Retrieved from http:// vietnamnet.vn/vn/thoi-su/227248/chat-6-700-cay-de-nghi-thanh-tra-chinh-phu-vao-cuoc.html 